\title{
DIGITAL TOKENS IN THE TOOLS OF MODERN FOREIGN TRADE ACTIVITIES BY ECONOMIC ENTITIES OF THE BRICS JURISDICTIONS ${ }^{1}$
}

\author{
Alexander I. Goncharov \\ Volgograd State University, Volgograd, Russian Federation
}

Marina V. Goncharova

Plekhanov Russian University of Economics (Volgograd Branch), Volgograd, Russian Federation

Introduction: computer algorithmization of production, transport, communication and other processes, which is actively distributed across the countries of all the continents, has received a special name-digitalization of the economy. The speed and independence from distance, in particular, the interworking algorithms for attracting investments are perceived by entrepreneurs with great hope for success. According to the authors of the paper, by 2022 the financial digital technologies can replace up to $28 \%$ of traditional banking and payment transactions, up to $22 \%$ of insurance and foreign trade financing transactions. In the short term, the relevance of introducing the legal regulation of digital investment tokens will be duly evaluated, so long-term foreign trade projects for long-term supply of goods, in particular, by the economic entities of the BRICS jurisdictions, will receive increasing financial support. In the scientific paper, the authors studied the activities of the Russian legislators on forming the legal regulation of the digital economy for the purpose of identifying their mistakes and shortcomings, as well as substantiating recommendations for the consolidation in the legislation of the viable legal structures which can be used by the economic entities of the BRICS jurisdictions in long-term foreign trade transactions that require large financial resources for a period of 1 year or more. Relying entirely on the materialistic worldview and the general method of historical materialism the authors used the general scientific and specific scientific (comparative law, normative-dogmatic, statistical, hermeneutic) methods for the study. As a result, the authors proved that the development of ICO investments would continue rapidly. The growing popularity of ICO will promote the technical "base" of the token market and strengthen the crypto protection of smart contracts and transactions within their performance. Tokens, as digital crypto records on the Internet resources, used by the participants of foreign trade transactions of the BRICS jurisdictions - the organizers of investments, by 2022 will become the usual investment instruments, such as bonds or shares. The conclusions and recommendations on the correction of the Russian bills are formulated; the proposals for improving the infrastructure of remote investments in the Internet space of modern Russia are given. On the basis of a critical analysis of the scientific works of the economists and lawyers, the authors formulate the definitions of the studied tools of remote digital interaction of investors and organizers of investment of long-term foreign trade transactions, which can be carried out including the economic entities of the BRICS jurisdictions.

Key words: digital space, civil law, bills, ICO-investments, crypto-records, foreign trade transactions, BRICScountries.

Citation. Goncharov A.I., Goncharova M.V. Digital Tokens in the Tools of Modern Foreign Trade Activities by Economic Entities of the BRICS Jurisdictions. Legal Concept, 2019, vol. 18, no. 3, pp. 31-42. DOI: https:// doi.org/10.15688/lc.jvolsu.2019.3.5

\section{ЦИФРОВЫЕ ТОКЕНЫ В ИНСТРУМЕНТАРИИ СОВРЕМЕННОЙ ВНЕШНЕТОРГОВОЙ ДЕЯТЕЛЬНОСТИ ХОЗЯЙСТВУЮЩИХ СУБЪЕКТОВ ЮРИСДИКЦИЙ БРИКС ${ }^{1}$}

\author{
Александр Иванович Гончаров
}

Волгоградский государственный университет, г. Волгоград, Российская Федерация 


\title{
Марина Вячеславовна Гончарова
}

Российский экономический университет им. Г.В. Плеханова (Волгоградский филиал), г. Волгоград, Российская Федерация

\begin{abstract}
Введение: компьютерная алгоритмизация производственных, транспортных, коммуникационных и других процессов, которая активно распространяется по странам всех континентов, получила особое название - «цифровизация экономики». Скорость и независимость от расстояния, в частности, цифровые алгоритмы межсетевого взаимодействия для привлечения инвестиций, с большой надеждой на успех воспринимаются предпринимателями. По оценкам авторов статьи, к 2022 г. финансовые цифровые технологии могуг заменить до 28 \% традиционных банковских и платежных операций, до 22 \% страховых операций и сделок по финансированию внешнеторговых сделок. В краткосрочной перспективе актуальность введения правового регулирования цифровых инвестиционных токенов будет должным образом оценена, поэтому все большую финансовую поддержку будут получать долгосрочные внешнеторговые проекты долгосрочных поставок товаров, в частности, хозяйствующими субъектами юрисдикций БРИКС. В научной статье авторы исследовали деятельность российских законодателей по формированию правового регулирования цифровой экономики с целью выявления их ошибок и недоработок, а также для обоснования рекомендаций по закреплению в законодательстве жизнеспособных правовых конструкций, которые могуг применяться хозяйствующими субъектами юрисдикций БРИКС в долгосрочных внешнеторговых сделках, требующих привлечения крупных финансовых ресурсов на срок от 1 года и более. Опираясь в целом на материалистическое мировоззрение, всеобщий метод исторического материализма авторы использовали для исследования общенаучные и частнонаучные методы (сравнительно-правовой, нормативно-догматический, статистический, герменевтический методы). В результате авторами обосновано, что развитие ICO-инвестиций будет ускоренно продолжаться. Рост популярности ICО продвинет техническую «базу» рынка токенов, усилит криптозащиту смарт-контрактов и транзакций в рамках их исполнения. Токены, как цифровые криптозаписи на интернетресурсах, применяемые участниками внешнеторговых сделок юрисдикций БРИКС - организаторами инвестиций, к 2022 г. стануг привычным инвестиционными инструментами, какими являются облигации или акции. Сформулированы выводы и рекомендации по корректировке российских законопроектов, даны предложения по улучшению инфраструктуры удаленных инвестиций в интернет-пространстве современной России. На основе критического анализа научных работ экономистов и юристов авторы формулируют определения исследуемых инструментов дистанционного цифрового взаимодействия инвесторов и организаторов инвестирования долгосрочных внешнеторговых сделок, которые могут осуществляться в том числе и хозяйствующими субъектами юрисдикций БРИКС.

Ключевые слова: цифровое пространство, гражданское право, законопроекты, ICO-инвестиции. крипто-записи, внешнеторговые сделки, страны БРИКС.
\end{abstract}

Цитирование. Гончаров А. И., Гончарова М. В. Цифровые токены в инструментарии современной внешнеторговой деятельности хозяйствующих субъектов юрисдикций БРИКС // Legal Concept $=$ Правовая парадигма. - 2019. - Т. 18, № 3. - С. 31-42. - (На англ.). - DOI: https://doi.org/10.15688/lc.jvolsu.2019.3.5

\section{Introduction}

Foreign trade deals, the intensity of which between business entities from the BRICS member countries has increased markedly in the last five years, require, as a rule, the attraction of large financial resources. Money paid for the goods and its delivery to the country of the buyer, then returned to the deal's supplier with a profit. Classic bank lending is not always in such situations acceptable to the organizers of the deal. Targeted financing from a group of investors can become quite an effective tool for financial support for a long-term foreign trade deal, and money can be attracted remotely using new digital technologies. Computer's algorithms of production, transport, communication and other processes, which is actively distributed throughout the countries of all continents, has received a special name - digitalization of the economy [8]. The speed and independence of distance, in particular, digital interworking algorithms for attracting investments, with great hope for success are perceived by entrepreneurs. According to the authors of the article, by 2022 financial digital technologies can replace up to $28 \%$ of traditional banking and payment transactions, up to $22 \%$ of insurance operations and transactions for financing foreign trade deals. In the short term, the relevance of the introduction of legal regulation of digital investment tokens will be properly evaluated, so all financial support will receive longterm foreign trade projects for long-term supply of goods, in particular, by business entities of the 
BRICS jurisdictions. In a scientific article, the authors investigated the activities of Russian legislators in the formation of legal regulation of the digital economy in order to identify their errors and omissions, as well as to justify recommendations for enshrining viable legal structures in legislation. Which can be used by business entities of the BRICS jurisdiction in long-term foreign trade transactions requiring the attraction of large financial resources for a period of 1 year or more.

The traditional instruments for obtaining the investment in the modern conditions are not enough. The development of the electronic technologies, the emergence and rapid growth in popularity, firstly, of the "electronic money", and in the recent years - crypto-tracings wrapped around in the Internet - predetermined the appearance in the international financial practice of the investment method, associated with investing in the promising projects namely virtual crypto-funds. The variety of projects offered to investors, competition in a wide range of areas (IT technologies, communication services market, telecommunications, etc.) determines that companies resort to using the more convenient and efficient instruments and sources of financing for its programs and projects. One of such instruments is ICO. According to the international statistics, in 2017, with the help of ICO, American entrepreneurs attracted more than 4 billion US dollars for their projects. According to The Economist magazine, in the field of venture capital investments for the potentially new projects related to some unique, unparalleled the technological or financial product, investment in the ICO market took a predominant share.

\section{Tokens - the digital crypto-tracings on the Internet-resources used by investment organizers}

In Russia, the first draft of the federal law "On the digital financial assets" was published by the Ministry of Finance of the Russian Federation in January 2018 ((URL: https://www.minfin.ru/ common/upload/library/2018/01/main/ Zakonoproekt_o_TSFA_250118_na_s ayt.docx). Based on the name of the regulatory act, it is clear that, according to the lawyers who developed the text of the draft law, there are stable public relations in the Russian Federation regarding certain assets, which need to be regulated. In our opinion, it is necessary, first of all, in the fiscal interests of the state itself, also declaratively in the order to protect the rights of the participants in its relations. In the understanding of the Ministry of Finance of Russia, it new assets of the XXI century have 2 special qualities, firstly, they are digital assets, and secondly, its assets are simultaneously financial. It should be borne in mind that its digital objects (we believe that there is no reason to call its assets) people will never be able to touch how the tangible things are, a person can see its digital objects only on the computer screen in the form of numbers inside special tables (registers).

The main concepts used in the draft federal law "On digital financial assets" include, in particular, "the digital financial asset". According to the lawyers of the Ministry of Finance of Russia, its property is in electronic form. Such property is created using the encryption tools on a computer by any subject according to his will and in his interests. The property rights of subjects on these ciphers are certified by making entries (also digital) in a special database. The draft federal law provides for 2 versions of the specified ciphers: a "crypto-currency" and a "token". According to the draft law, the legal nature of the digital objects is as follows: these are long sets of numbers with cipher functionality. In our opinion, the well-established understanding of the term token - the sign - is mistakenly used with a different meaning. In the draft of federal law translated into Russian legal language, token is a type of cipher, which is issued by a legal entity or an individual entrepreneur in order to attract financing and is taken into account in the register of the digital tracings. What is the register of the digital tracings, by whom it is kept, where it is stored, we do not find anywhere in the draft federal law. Through the thick veil of incomprehensible words, which are unknown for what are attracted to the draft federal law, we can identify the $2^{\text {nd }}$ version of the digital object "token" - it should be understood as the digital crypto-tracing - an offer (emission instrument). In this regard, we allow the use of our more correct term - an investment digital cryptotracing. 
After the adoption by the State Duma of the Federal Assembly of the Russian Federation in the first reading by mid-2018, the draft was substantially revised and now constitutes a new draft, that does not contain a number of glaring flaws. The most controversial terms are excluded - "cryptocurrency", "mining", "smart contract", procedures for issuing "tokens", "ownership of a digital financial asset", etc. At the same time, in the material world no one has cancel a wide range of repeatedly tested means of epy attracting investments, including at the sub-federal level. For example, in 2017, the Volgograd region placed on the Moscow Exchange PJSC the entire issue of its coupon bonds RU35007VLO0 with a nominal value of 1,000 roubles in the amount of 10 million bonds for the amount of 10 billion roubles [7]. In our opinion, the mechanism for acquiring a package of shares of an economic entity by its major partner is fully operational. Thus, in 2015, the plant of the NikonMag CJSC company RUSNANO was launched in the Volgograd Region, producing the nano-structured magnesium hydroxide (the effective flame retardant), the high-purity magnesium oxide (the transformer steel and rubber products) and the magnesium chloride (the oil and gas production, building materials, anti-icing structures and mechanisms). The total budget of the project is 3.8 billion roubles, of which RUSNANO's investment in shares is 1.3 billion roubles [3].

The investment digital crypto-tracings create in the form of a set of new unique ciphers, each of which is equal to one settlement unit, the organizer of investment itself. This process is called ICO - Initial Coin Offering. Its innovative way of attracting the real money (dollars, euro, pounds, yuan, roubles, etc.) is a prototype for the minting of the unique coins for a specific investment project. For example, in order to finance a project to get milk from the ordinary green grass (without a cow), a Russian joint-stock company publishes its digital investment cryptotracings - milk-coins - in the Internet. According to the conditions offered by the investment organizer, one milk-coin is equal to one euro. If an investor at his own risk and in his own interests decides to invest his capital in this project, he will receive the Internet's crypto-tracings in the investor's register for his euro, its crypto-tracings are conventionally named by the investment organizer himself milk-coins. Against the 1 million euro invested in the project, the investor will have 1 million milk-coins respectively.

It should be noted that, of course, the investor does not receive any newly minted coins, in order to confirm his investment of 1 million euro, he receives only the encrypted entries in the investor register. Which, except for the investors themselves, and only in relation to themselves and their investment amounts and operations of the investment organizer, is no longer available to anyone. No matter how many investors to participate in a particular project, the process of implementing an investment project can be organized in such a way that the investors will never know exactly who participated in the investment transactions, how much money each of them invested in the project. We believe, in order to facilitate the perception of the investors, as well as to facilitate the work of the investment organizers - eliminating the need to invent each time the name of the new initiative coin in the next investment proposal, everywhere on the Internet entrenched the term - "token". In the investment deals, it is a type of cipher; it is a crypto-tracing in the registry, confirming that the investor has made real money in a particular project. The Russian legislator, in his drafts, is not particularly bothering and deeply plunging into the essence of cipher's computer matter, easily uses the words "crypto-currency" and "token".

The peculiarity of ICO - initiative monetary (coin) offer - there are a decentralization, simplicity, cross-border accessibility, absolutely fiduciary nature, complete anonymity of investors, transparency and controllability of all operations of the investment organizer with funds received from investors. Each operation carried out by the organizer of the investment in the framework of the initiative coin offer is duplicated and addressed to each investor, approved by the investor, then encrypted and can never be changed or distorted in any way. In 2018, hundreds of similar ICOs were conducted without a state registration in any jurisdiction. In the Internet, on the specialized websites, you can find the information that in 2017 235 ICO were sold, which is 5 times more than in 2016. Its initiative monetary offers allowed to attract more than 3.7 billion US dollars, compared with 96 million US dollars in 2016. The lists of the current ICOs can be found on coinschedule.com 
and other websites. For example, in early 2018, the LavkaLavka Farmers Cooperative attracted investments for the period from January 1 to February 18, 2018 in the amount of more than $\$ 16$ million. Thus, the cooperative has exceeded the maximum ICO fundraising level set for the BioCoin platform in the amount of $\$ 15$ million. The cost of tokens changed during the ICO: throughout January, 31.5 BIOs could be purchased for $\$ 1$, and in February only 24 BIOs could be bought with the same money. The total number of tokens sold during the ICO period is not disclosed. Total farmer cooperative released 1 billion. BIO. In the autumn of 2017 , ICO LavkaLavka raised about $\$ 2$ million during the pre-sale. The attracted investments should be directed to the implementation, launch, support and promotion of the block-chain platform BioCoin: the technological development, expansion of the client base, marketing, searching for new partners, opening new outlets, etc. The main expenses will be associated with an increase in the number of users of BIO tokens (URL: https://cryptorussia.ru/ news/lavkalavka-otchitalas-ob-uspeshnomzavershenii-ico).

Let us ask ourselves a sceptical question, whether the ICO boom is not yet another financial bubble. After all, there were a lot of its in history. The historical classic here is the price bubble for tulip's bulbs, it burst in 1637 in the Netherlands. In those years, the Netherlands - the only country in the Old World, in which power was controlled not by noblemen, but by businessmen - oligarchic families. Consequently, it was here that the prerequisites for a rapid economic growth were created. The Netherlands is the economic leader of that time, growing faster than all states in the continent, but there is always a risk of overheating of the economy. Even now, its risks are often underestimated, what can we say about people of the $17^{\text {th }}$ century, who did not operate with such concepts. In the Netherlands, goods from the East were particularly popular. The flowers from the Ottoman Empire were most appreciated - tulips, and the peak of the price increase was in 16341637 , undoubtedly, it was a speculative race. Flowers are a seasonal commodity, but the demand was so high that the merchants created a special place, where it was possible to trade flowers all year round - Tulip Exchange. And here we come to the most important thing - a futures contract was invented - the delivery of flowers of the future harvests at a predetermined price. The bubble pouted to its peak and burst, many entrepreneurs collapsed, the country's economy shook well, and a recession occurred, Europe plunged into crisis. But it is of little importance in the long run, but the discovery of a new way of the economic relations is very important. The futures were created, without which it is impossible to imagine the modern exchange relations - it is the main boom result and bursting the bubble of the tulip-mania.

In France, when Louis XV came to power, there was no gold in the treasury of the state to mint coins with a portrait of the new King. And then, on the advice of John Law, an economist under the French government, they decided to create a bank that would print the paper money. The banknotes in Europe since 1661 have already been used in Sweden. But it was after the wide circulation of the paper money in France (due to the shortage of gold) that the circulation of the paper banknotes began in Europe and then around the world. The French bank printed a huge amount of unsecured money, it number many times exceeded the welfare of France. John Law proposed to declare, that Louisiana is a new French colony is incredibly rich in gold. The idea was to attract the investments for this version, and with the help of the money received from investors, it was planned to solve the problem with the unsecured banknotes. Nevertheless, the bubble burst, because there was no gold in Louisiana. A deep crisis and strong inflation have fallen on France, but the paper money has entered in the daily turnover, and is still of great importance in the money circulation.

The beginning of the XXI century - the dotcom's bubble, an Internet mania swept all the developed countries, a capitalization of the Internet companies has grown very quickly. The whole business sought to go online, but even the financially sustainable, high-tech and efficient companies were overvalued, besides those, which only gave the appearance of successful work for the sake of entering the IPO and ensuring the growth of the market value of its shares by waiting for miracles from the transition of the economy to the new era of the Internet technologies. The problem was in the substitution of the concepts: the Internet was perceived not as a tool for 
developing the real economy and improving business processes, but was replaced by the idea of a completely new a digital Internet economy without reference to the actual production of the goods, fulfilment of work, and provision of services. On this misconception, the bubble has grown and burst, taking with it many ineffective and non-productive Internet companies. The bubble caused a crisis, stagnation, short-term distrust of the IT-sphere. However, there were positive consequences, the prices for the server equipment and personal computers decreased significantly, its accelerated the spread of the information technologies [6]. The dotcom's bubble left understanding: the Internet and business are closely connected. The XXI century is the age of the digital economy; it's almost impossible to imagine a large company, that would not use the Internet technologies. In our opinion, the financial bubbles inevitably burst, but its leave behind something new and useful. The products of bubbles are the gains of a humankind that can and should be used to develop the civilization, the economy, and increase people's well-being. Obviously, the ICO is not always safe, for example, in 2017, the cybercriminals managed to steal $10 \%$ of the funds invested in the ICO through the Ethereum. But using the Ethereum, most often projects goes to ICO [5]. Therefore, a security is the first thing which block-chainenthusiasts should pay attention to when creating the projects, bringing to the ICO [2]. Above, we gave examples of the successful projects, but there are hundreds of examples of the companies that went through ICO disappeared without a trace. Thanks to the successful projects, a fashion for the ICO has arisen, many projects are in a hurry to get into the spotlight, grab their part of a big financial pie. In our opinion, the amount of money raised by the ICO will increase, the number of unsuccessful projects will increase too, the situation by analogy with the dotcom's boom will probably recur.

The ICO-instrument is similar not only in its sound, but also in terms of its actual content with the IPO-instrument - the initial public offering on the stock market. However, during the IPO procedure, the investor receives real shares (thereby acquiring the possibility of guaranteed receipt of dividends in case of success of the investment project, and (or) the opportunity to participate in the direct management of the jointstock company). But with the ICO, any investor gets the crypto-tracings - tokens - provided only with an idea, transformed into a tempting financial result in the future. The investing with the ICO involves the several stages in this procedure.

1. The initial (preliminary) stage associated with the direction of proposals for potential investors to purchase tokens. At the initial sale stage, the so-called "private sale" of the investment assets occurs. At this stage, representatives of the project attracting the investment are sending offers to those participants in the financial market, who, according to the administration of the investment project, are most interested in the subsequent to invest of the capital in the project. For this stage, it is necessary to determine the final amount of the amount of the investment that will be required to implement in the project, as well as the investment's risks of the project. The negative outcome of this stage is the lack of the interest in the project, therefore a preliminary determination of the circle of the potential investors is a difficult and responsible task. The conditional approbation of the investment project takes place on a "focus group", which with due interest in the financial results that the project offers, is an important guarantee for the involvement in the project of an increasing number of the investors, who are ready to invest significant sums of money in it.

2. The stage of the "conditional" placement of the tokens - a kind of the "stock" of the electronic investment's Internet-project - is intermediate, and not always carried out. At this stage, a certain share of the tokens is sold (as a rule, no more than $30-35 \%$ of the total number of the tokens, that are supposed to be issued as part of the investment of the project) to investors, who are interested in the prospects of the project during its "private sale". This stage is valuable not so much by the possible financial revenues as by increasing the attractiveness of the project for investors, the prospects for its further progress. By tracking how actively the pre-informed investors buy the tokens, the project administration assesses, first of all, the effectiveness of the project's advertising campaign conducted during the initial notification. The high degree of the interest of the large investors in the project allows you to reduce the advertising costs. Investors' 
money received at this stage most often goes not for the implementation of the investment project, but for the current logistical and advertising needs - which also works to develop the project.

3. At the stage of the final placement of the tokens is it sale. In the contrast to the two previous stages, here the widest range of the market participants is offered to acquire their share in the investment project. The low "threshold" of entry is ensured by the low cost of the tokens - as a rule, the tokens at this stage can be purchased in very small packages, its cost from several tens to two or three hundred US dollars. Such availability of a project often leads to an even greater increase in its popularity - which, in turn, ensures the involvement of the large amounts of the investment.

The investment operations in the framework of the ICO-procedure involve the use of a specific technology to acquire the tokens - it is the signing of smart-contracts. A smart-contract is a special code of the computer program, with the help of which the opportunity to directly carry out a deal. In addition, through the use of a smart-code, the participants in deals to acquire the tokens have the ability to track the fate of the investment assets, to participate in the negotiations, sign the additional agreements on already acquired or the potentially acquired project's tokens, as well as to monitor the fulfilment of the terms of the deal by the administration of the investment project. The smart-code serves primarily as an additional guarantee of the security (in this case, the informational security) of the investment activities carried out through the implementation of a cryptocurrency. In addition, such an individualized deal's procedure effectively excludes the possibility of the influence on the terms of the deal by third parties. Also, the smart-code helps to simplify some actions related to the fulfilment of the contract - for example, by sending the automatic messages about the change of the token's rate. Also the smart-code mode's feature is that within the framework of its use only access is available to the number and composition of the investment assets in the relation to which the deal has been signed with a certain investor. The smart-code algorithm makes it possible, in the presence of an external security threat and data immunity, to block access to it - or to restore such access automatically for the participants in the deal while neutralizing the threats. Also, the secrecy of the smart-contract data is ensured that the parties to the deal have a secret access key - a special password that grants access to the control and disposal of the tokens only to the owners of such key. Here it is necessary to pay attention to the legal consequences of signing the smart contract when making the deals with tokens. Thus, a person who, in a similar way, enters into an investment relationship, is recognized as duly notified of the substance and conditions of the investment's deal. It follows from this that the possible established a discrepancy between the initial terms of the deal and the content of the smart-contract can be decided in favour of the person, who refers to the initial conditions, only when it was established, that such person did not know and did not have a real opportunity to know about such discrepancy, because the person was not allowed to form the smart-contract.

Let's pay attention to the essence of the token, as a kind of the crypto-analogue of the stock in the digital investment's legal relations. According to the generally accepted understanding of its legal and economic essence in the modern theory, the token itself is a kind of asset that exists exclusively in the digital space. By analogy with the stock, the token provides an opportunity for the investor to make a profit or other benefits and the advantages in the connection with the sale of the final product that will be created as a result of investing in the ICO market. In addition, the availability of the token to the investor provides him with the opportunity to influence on the activities and further development of the investment project. It is interesting to compare the token with another digital economic tool, which actively developed and used in recent years crypto-currency. Since the token is essentially the digital crypto-tracing acquired for the cryptocurrency, it is also created on a predetermined technology platform, it must be borne in mind that not every token can be the independent cryptocurrency. The token is immersed in a certain "coordinate system", tied to a specific area of the electronic economy, therefore, not all tokens created during ICO investment can be used as an independent asset. In Russia, at the legislative level, the category "token" has not yet been disclosed. In our opinion, it is only a matter of time - because the progressive development of the information technologies will sooner or later 
require from the legislator to develop a single regulatory approach to the implementation of the crypto-currency investment - in the target to protect not only the investors and investment projects themselves, but also to ensure a general economic security, law-order in the financial sphere, to prevent the laundering of the illegal income using the crypto-tools.

First of all, in the order to determine the legal nature of the tokens in a number of other financial instruments, we will consider its classification. The most common in the modern theory of the financial and informational law is the grouping of tokens produced, depending on the functions and role its play in the electronic economy. Based on this criterion, stand out:

1) the incorporated (or embedded) tokens, which by their very nature act as independent financial instruments. Thus, according to the current Russian civil legislation, the embedded token will be equated to non-documentary security. In this situation, a token gives the investor the same rights as if he had a stock of a joint stock company;

2) the tokens, in the provision of which lies some certain obligation. Its tokens are similar to gift certificates;

3) the "digital goods" - tokens, which is any other property not specified in the legislative act.

The classification of the tokens by M. Yurasov deserves attention, this indicated author relates the legal and economic "weight" of the token to specific civil law contracts, the subject of which can be such peculiar property [10]. Thus, in accordance with the content of the contracts provided for by the Civil Code of the Russian Federation, tokens can be divided into the following.

1. The software tokens (application tokens). Such financial instruments are a full-fledged "digital currency" - its provide access to the information resources that are necessary to fulfil obligations under a smart-contract. For example, the Flucoin token facilitates the secure storage of a data on the hard disks of the several hundred computers at once. Such decentralization allows for a greater degree of the security of operations - than if all a data were stored on a single server. After all, in case of the interruptions in its work or a complete shutdown, all smart contracts that are executed on the basis of its token would be jeopardized. Analogous to the use of tokens-applications in civilian turnover are the sale and purchase, exchange, option and licensing agreements.

2. The token - quasi-stock. The use of such token in the ICO-investment is accompanied by the opportunity for investors to receive in the same tokens the specifically designated dividends from the practical fulfilment of the investment project. A certain income can also be obtained as a result of storing tokens on the distributed servers, and other transactions within the same investment project or the several projects by the same author. At the same time, the percentage received by depositors from the use of a token may be different and set at the preliminary stages of signing a smartcontract. For example, as part of the use of the tokens from Sia's network contracts, the "holders" of such tokens are paid almost $4 \%$ of each transaction - these are the so-called "income for storing the information". It seems that such dividends are quite comparable in its volumes with the profitability of large companies that issue shares. The analogue of such operations in the "real" civil turnover are the lease agreements, partly the loan agreements, the option agreements (if the latter is connected with the transfer of the share in the corporation). In the process of using the tokens - quasi-stocks, it must be borne in mind that, according to the laws of many countries (including the Russian Federation), the token does not grant any corporate rights. Based on this, in target to more effectively protect the rights of the investors in the token's projects, it is necessary to use one of the above contractual structures.

3. A specific form of epy tokens are its crowd-funding varieties, which do not provide to investors with any property rights. The investor voluntarily submits to the electronic investment project a part of his property expressed in a certain number of the issued tokens. It should be guided by the rule of the article 575 of the Civil Code of the Russian Federation, according to which donations between the legal entities are prohibited.

To consider the contract, the subject of which is the token, should be based on its type, so we can distinguish the following types of contracts:

- the implementation of the exchange operation in the crypto-currency market;

- the contract of sale (the participation in an investment project, implying some the material or managerial benefits, in exchange for a part of 
the investor's property expressed in cryptocurrency);

- the license contract (the acquisition by the investor of some exclusive rights to an intellectual product, which will be created as a result of the investment project);

- the paid service contract (if the payment is directly caused by the storage on the investor's computer of a certain amount of the information allowing the administration of the investment project to carry out the operations with cryptocurrency as part of the execution of the project itself or a group of similar projects);

- the contract of sale of the nondocumentary securities (for those tokens, the price of which is confirmed by the opportunity to receive the direct benefits in the framework of the smartcontract);

- the cession contract, the assignment contract of the preferential right (related to the opportunity to assign the share in the investment project to another person or to the group of persons);

- the contract of endowment (if the purchase of a token does not entail the prospects of obtaining any property rights, but acts only as a kind of "endowment" by a person who has a disinterested opinion in the implementation of the investment project).

In general, in Russia, the useful potential of the ICO market is still not fully appreciated in a situation of growing informatization and digitalization of the financial activity. At the same time, there are a number of the practical problems faced by investors during the direct implementation of the smart-contracts. Based on the analysis of the relevant theoretical sources, we will identify 6 causes of such problems [9].

1. The lack of "pegging" of the rate of the value of the crypto-currency tokens produced to the specific indicators of the work of an organization, that issues an investment financial instrument (for example, the stocks of the oil companies are almost the directly dependent on the current dynamics of the oil prices).

2. The incomplete legal framework in the use of the electronic financial instruments, both in the market in general and in the investment activities, in particular. For example, when placing the tokens, resident issuers of the some states may face accusations of the illegal collection and laundering of the funds (for the countries where there is currently no legal regulation of cryptocurrencies).

3 . The collisions occurring in the conflict of the rules established by the smart-contract (as defined by the customs of the ICO-investment), and the requirements of the current positive financial, tax and civil law. For example, the legislation of many developed countries, where the volume of the ICO investment market reaches an impressive scale, has still not resolved the question of which the tax system to apply to the transactions related to the issue and turnover of the tokens.

4. The objective inability to fully control the operations in the crypto-sphere of the Internet, its compliance with the legal requirements, as well as the inability to track the entire "chain" of one specific operation. Because very often the use of the tokens is associated with the additional encryption and automatic change of IP addresses, the use of technologies with the inability to track the Internet traffic (Tor browser and other socalled "anonymizers"). In our opinion, it follows from the very nature of the crypto-currency, which was thought of as an opposition to control by the state and other interested parties when making payments on the Internet.

5. The specifics of the venture capital investments, as one of the types of the investment activities. The final result of the investment project is not fully known, therefore the character of the investment aimed at the "future" in those products whose market efficiency and practical benefits are not fully computed under any circumstances. Such venture projects will always be risky for the investor, who intends to invest his property in some of the smart-contracts, provided even if the crypto-currency is demanded and actively sold for the money.

6. Also from the character of the investment implies a problem that is much longer than the other types of the investments - the timing of the investment project. In practice the investors in the ICO market often face with the lack of growth in the cost of the token, since the project in which they invested their funds has not yet received adequate demand, or has not yet reached the final product stage. For example, a computer program, in the creation of which funds were invested, is still being developed as part of the project, the risk to fall out in the cost of the token. 
We agree that a significant difficulty for the investors wishing to invest in the tokens is caused by assessment of the real market value and profitability of the token, produced to support one or another ICO project. Indeed, the venture character of the investments made in the field of the crypto-currency does not allow to accurately calculate the cost and the possible benefit from the implementation of the funds spent on the project. For example, if we are talking about some kind of innovative medical radio engineering means, within the framework of which an investment project is formed. Taking into account the possible high demand for this product on the market, it an uniqueness, convenience in mass production and efficiency in practice - the possible benefits and risks are quite predictable and, if possible, the avoidable [4].

A completely different situation arises when making the investments through a smart-contract. The actual assessment of the cost of the cryptocurrency is very complex, and depends on a number of the factors that must be considered at the initial decision stage at the "personal offers" stage of the smart-contracts to the investors. In practice the complexity of assessing the real value of the proposed projects leads to the diametrically opposite indicators of the growth in the cost of the tokens, even within the same investment sector. So, the price of the some tokens can easily soar in dozens and even hundreds of times (as was the case, for example, with Bitcoin crypto-currency in the autumn 2017), while the other financial instruments can rapidly fall in price (as is currently the case with tokens produced within the Ethernium network). As an example, the materials of the information report of the international company Ernst \& Young, which execute the analytical measurements on the crypto-currency market, can be cited: at least few dozen smart-contracts lose its value completely every month (retaining from 0.0001 to $0.5 \%$ of the initial price).

There are several conditions that should be able to be fulfilled by persons who wish to invest their property in the ICO project:

1) the forecast of the development of the investment project in the future, depending on the analysis of the implemented investment projects of the same initiators, or on the analysis of the projects of other authors in the same field of the economic activity;
2) the creation of the standard financial models adopted in the venture capital market in the investment market using the tokens;

3) the analysis of the proposed or signed and implemented the smart-contract itself-based on the ratio of the services offered under the smart-contract and the financial instruments spent on its execution, the analysis of its value. Here, as an additional criterion for the comparison, also we can use some weighted average cost of service in the smart-contracts of the market segment under consideration.

\section{Results}

In our opinion, a significant problem in the ICO investment market is ensuring the technical safety and technological accuracy of the tokens produced in the framework of the ICO project. First of all, it is necessary to ensure the accuracy of the execution of the commands during the signing of the smart-contracts. The program code of the contract must be the completely invulnerable, both from external threats (the computer viruses, "hacker" programs), and possible the internal intervention associated with the unfair actions of the administration of the investment project. Based on its, the specialized automated systems are currently being actively developed, the specifically for the smart-contracts, offering the special measures in relation not only to the tokens produced, but also to the personal data of the investors, other information that is confidential.

The relevance and importance of its problem is also supported by the fact that specialists from the leading technological universities, scientific and technical laboratories in Europe and the USA (for example, the Massachusetts Institute of Technology) are engaged in creating new and improving the created programs for the smartcontracts. So, for example, at the moment in the world practice of the ICO-investments the use of two security programs - ICO Hawk and Enigma are most common. The principle of the operation of its programs is built on the additional confidentiality of the transactions and financial flows. Each element of a smart contract - the information about the parties of the contract, the essence of the project, the encrypted financial flows themselves, the transactions involving crypto-currency - is encoded in a special way, 
which does not allow access to any one element of the contract without the decryption keys from all other components. In addition, an important technical advantage of using its systems is the possibility of returning funds as a result of its loss for reasons beyond the control of the parties. With the established bad faith of the contracting party and the termination of the contract, the systems also provide (after a certain control period) the return of the spent money to the investor. Thus, an example of a real positive action of the Hawk security system was the return of more than thirty million dollars to various contributors of the DAO smart system (issuing the Ethernium cryptocurrency) after a hacker attack on the server system in 2016.

The impossibility of making any unscrupulous or outright illegal changes in the signed smart- contract seems to us not only an important regulator of the good faith behaviour in the market for ICO-investment. The technical reliability of a smart-contract against the distortion is the most important real promising for the widespread implementation of the cryptopayments in all areas of the property turnover. In the State Duma of the of the Federal Assembly of the Russian Federation is actively discussing the inclusion of block- chain technologies in the legislation on a procurement for the state and municipal needs. For example, in the framework of the round table "State booking - for fair purchases" held in January 2018, Deputy Head of the Federal Antimonopoly Service of Russia R. Petrosyan made a report on the possible use of the smart-contracts and block-chain technologies in the process of the state and municipal procurement. A contract signed in this way will not be able to be corrected without the obvious external changes in the hindsight. Such transparency of the contract will be a worthy stimulus for the development of a competition, first of all, among the small and medium-sized businesses, its more active participation in the auctions and tenders. In addition, the tracking of the incorrect amendments to the smart-contracts will allow the authorities exercising antimonopoly regulation to track and identify the unscrupulous participants in the procurement system - both from the subjects of the economic activity and among the state and municipal organs (URL: https://fas.gov.ru/ publications/14342).
In our opinion, this perspective is very interesting and enhances the overall level of a transparency not only of the procurement activities. The presence of a public participation (not only as a party to the contract, but also to the organ, that controls the legality of the deals) will allow developing the effective mechanisms to protect the rights and legitimate interests of the parties of a smart-contract. In turn, also such mechanisms can be borrowed and extended to the private sector of smart-contracted, namely with the ICO investing. It will increase the attractiveness of the crypto-tools in the commercial turnover, however, it should be borne in mind that at the same time it may give rise to active opposition to the developed methods for monitoring and ensuring the security of the projects, which, in turn, will require the development of the additional technologies [1]. Such opposition, in our opinion, is inevitable, it follows from the very essence of the cryptosphere, which arose precisely as a "response" to the official monetary system.

\section{Conclusion}

The development of ICO-investment will continue to accelerate, the investment of capital with the help of this tool will increase exponentially. Already today, rating and consulting agencies that work exclusively in the sphere of ICO are being formed, which undoubtedly indicates the interest of the investment elite to include crypto tools and operations with them in their circle of interests. In our opinion, in Russia in the short term, the importance of introducing legal regulation of the circulation of investment tokens will be properly appreciated. The growing popularity of ICO will lead to the development of the technical "base" of the token market, strengthening of crypto protection of smart contracts and transactions as part of its execution. Tokens, as digital cryptotracings on Internet resources, used by participants of foreign trade deals of the BRICS jurisdictions the organizers of investments, by 2022 it will become familiar investment tools, such as bonds or shares. These tools for remote digital interaction of investors and investment organizers of longterm foreign trade deals will contribute to the intensification of trade operations of business entities of the BRICS jurisdiction. 


\section{NOTE}

1 The reported study was funded by RFBR according to the research project No. 18-29-16132 "Priorities for the legal development of digital technologies of foreign trade activities in the context of international economic integration".

\section{REFERENCES}

1. Ermolaev K.N. Bitcoins as a Form of Fictitious Capital: The Genesis, Essence, Dialectics of Development. Economic Sciences, 2017, no. 7, pp. 11-14.

2. Inshakova A.O., Popkova E.G., Goncharova M.V. Transformation of Non-Cash Money in Banknotes: Demand, Supply, the Subjective Side of the Crime. All-Russian Criminological Journal, 2018, no. 3 (12), pp. 366-374.

3. Inshakova E., Inshakova A. Nanomaterials in the Power Engineering Industry: Market Trends and Application Prospects. International Conference on Modern Trends in Manufacturing Technologies and Equipment (ICMTMTE 2018). MATEC Web of Conferences, 2018, vol. 224, p. 8 .

4. Inshakova E.I., Ryzhenkov A.Yu., Inshakova A.O. Neo-Industrialization of the Russian Economy: Technological and Digital Development.
Popkova E.G., ed. Ubiquitous Computing and the Internet of Things: Prerequisites for the Development of ICT. Cham, Springer Science + Business Media, 2019, vol. 826, pp. 239-250.

5. Lazarenko A. How to Steal Money at ICO. Hacker, 2018, no. 3 .

6. Mankew N.G. Macroeconomics. Saint Petersburg, Peter, 2013. 560 p.

7. Order of the Finance Committee of the Volgograd Region of January 16, 2018 No. 8 "On Approval of the Report on the Results of the Issuance of Government Securities of the Volgograd Region for 2017”. URL: http://volgafin.Volgograd. ru/upload/ iblock/f03/Prikaz-komiteta-ob-utverzhdenii-otchetaob-itogakh-emissii-za-2017-god.pdf.

8. Tarakanov V.V., Inshakova A.O., Dolinskaya V.V. Information Society, Digital Economy and Law. Popkova E.G., ed. Ubiquitous Computing and the Internet of Things: Prerequisites for the Development of ICT. Cham, Springer Science + Business Media, 2019, vol. 826, pp. 3-15.

9. Yankovsky R.M. State and Crypto-Currency: the Problems of the Regulation. URL: http://msu.edu. $\mathrm{ru} /$ papers/yankovskiy/blockchain.pdf.

10. Yurasov M. Smart-Contract and the Prospects for its Legal Regulation in the Era of the Blockchain Technology. URL: https://zakon.ru/blog/2017/10/9/.

\section{Information about the Authors}

Alexander I. Goncharov, Doctor of Sciences (Jurisprudence), Doctor of Sciences (Economics), Professor, Department of Civil and Private International Law (Base Department of the Southern Scientific Centre of the Russian Academy of Sciences), Volgograd State University, Prosp. Universitetsky, 100, 400062 Volgograd, Russian Federation, gimchp@volsu.ru, goncharova.sofia@gmail.com, https://orcid.org/ 0000-0001-6580-4104

Marina V. Goncharova, Doctor of Sciences (Economics), Professor, Department of Economics, Plekhanov Russian University of Economics (Volgograd Branch), Volgodonskaya St., 11, 400131 Volgograd, Russian Federation, reu-kafedra-ekonomiki@mail.ru, goncharova.sofia@gmail.com, https://orcid.org/0000$0002-1480-4574$

\section{Информация об авторах}

Александр Иванович Гончаров, доктор юридических наук, доктор экономических наук, профессор кафедры гражданского и международного частного права (базовая кафедра ЮНЦ РАН), Волгоградский государственный университет, просп. Университетский, 100, 400062 г. Волгоград, Российская Федерация, gimchp@volsu.ru, goncharova.sofia@gmail.com, https://orcid.org/0000-0001-6580-4104

Марина Вячеславовна Гончарова, доктор экономических наук, профессор кафедры экономики, Российский экономический университет им. Г.В. Плеханова (Волгоградский филиал), ул. Волгодонская, 11, 400131 г. Волгоград, Российская Федерация, reu-kafedra-ekonomiki@mail.ru, goncharova.sofia@gmail.com, https://orcid.org/0000-0002-1480-4574 